\title{
Trade-offs between wood production and forest grouse habitats in two regions with distinctive landscapes
}

\author{
Helena Haakana ${ }^{1 *}$ (D), Esa Huhta ${ }^{2}$, Hannu Hirvelä ${ }^{1}$ and Tuula Packalen ${ }^{3}$
}

\begin{abstract}
Background: Forest management affects the viability of forest grouse populations, causing alterations to habitat quality. At the regional level, common targets for wood harvesting and safeguarding of specific habitats are negotiated between various stakeholders. Analysing potential trade-offs between forest grouse habitats and wood production in the region could support resource-smart decision making.

Methods: In this paper, we compiled trade-off curves represented as production possibility frontiers demonstrating the relationship between forest grouse habitat area and wood removal, using a Finnish forestry dynamics model and the Finnish Multi-Source National Forest Inventory. For the modelling of forest grouse habitats, a landscape-level occurrence model based on nationwide wildlife triangle census data was used. Five alternative forest scenarios in terms of wood removal were compiled for two study areas in Finland representing two different landscape structures.

Results and conclusions: Results showed that impacts on forest grouse habitats were case-specific. In the southern study area, increasing the roundwood harvesting rate affected grouse habitats more strongly as forests were already fragmented for other land uses and became more spruce-dominated over time. If the maximum sustainable removal rate was implemented, predicted grouse habitat area was $55 \%$ less than in a no-removal scenario. In the eastern study area, a more heavily forested region, the decrease was far lower at 22\%. Scenario results were also compared to levels of recorded (business as usual) wood removal and that envisaged by valid regional forestry programmes, and their sustainability in terms of grouse habitat area was discussed. The production possibility frontiers calculated in this study support the evaluation of the loss of suitable habitat caused by different wood harvesting rates, or vice versa, the economic cost of increasing habitat areas.
\end{abstract}

Keywords: Forest grouse, Forest landscape, Habitat model, Production possibilities frontier, Scenario analyses, Wood production

\section{Introduction}

The need to replace fossil-based materials and energy has triggered increasing demand for renewable resources (McCormick and Kautto 2013). In Finland, the National Forest Strategy (2015) aims to increase annual roundwood removals by 2025 to meet the needs of a growing bioeconomy (The Finnish Bioeconomy Strategy 2014).

\footnotetext{
* Correspondence: helena.haakana@luke.fi

${ }^{1}$ Natural Resources Institute Finland (Luke), PO Box 2, Fl-00791 Helsinki, Finland

Full list of author information is available at the end of the article
}

This has escalated concerns about the ecological sustainability of an increased exploitation of forest biomass. As such, there is a need to better understand the value trade-offs between wood production and other ecosystem services, such as biodiversity and wildlife. Agriculture in combination with infrastructure and modern forestry have significantly altered landscape composition and configuration of boreal forests, changing the dynamics and structures of these forest landscapes. Species vary in their sensitivity to human-induced changes to their habitats, and species that suffer the most from habitat

\section{Springer Open}

(c) The Author(s). 2020 Open Access This article is licensed under a Creative Commons Attribution 4.0 International License, which permits use, sharing, adaptation, distribution and reproduction in any medium or format, as long as you give appropriate credit to the original author(s) and the source, provide a link to the Creative Commons licence, and indicate if changes were made. The images or other third party material in this article are included in the article's Creative Commons licence, unless indicated otherwise in a credit line to the material. If material is not included in the article's Creative Commons licence and your intended use is not permitted by statutory regulation or exceeds the permitted use, you will need to obtain permission directly from the copyright holder. To view a copy of this licence, visit http://creativecommons.org/licenses/by/4.0/. 
shifts are either habitat or resource specialists with poor dispersal ability, or species affected by transformed inter-specific interactions in these communities (Angelstam 1992; Andrén 1995; Moilanen and Hanski 1995). The relationship between suitable habitat area and breeding success or population density can be nonlinear; there can be certain thresholds where only a slight reduction in habitat area can cause an abrupt drop in habitat connectivity (Andrén 1994). Knowing how individual species respond to habitat loss allows us to better understand how changes to their habitats affect their population survival.

In Finland, populations of forest grouse to include black grouse (Tetrao tetrix L.), capercaillie (T. urogallus L.) and hazel grouse (Tetrastes bonasia L.), have declined severely over the past forty years (Valkama et al. 2011). Changes to the landscape and forest structure due to forest management (habitat loss, habitat degradation, forest fragmentation), increased predator densities, excessive hunting, and adverse climatic changes have been implicated in this decline (e.g., Helle and Helle 1991; Storaas et al. 1999; Kurki et al. 2000; Ludwig et al. 2006). Several studies on the structural features of landscapes and forest stands for grouse habitats indicate how forest felling may negatively affect their populations (e.g., Rolstad 1989; Klaus 1991; Storch 1993; Åberg et al. 2003; Miettinen et al. 2008, 2010; Sirkiä et al. 2010; Wegge and Rolstad 2011; Huhta et al. 2017). The safeguarding of grouse habitats is urgently needed to ensure the survival of forest grouse populations in boreal forest landscapes over the long term. In Finland, results of recent studies have been used to define game-friendly guidelines for forest management (Lindén et al. 2014). Knowledge of species habitat requirements can be used in forest planning to identify stands where forest management should be adapted to provide optimal conditions for forest grouse. If adaptive measures lead to economic losses in wood production, forest owners need to decide whether the gain in game is worth the costs. However, some forest owners have shown an interest in alternative forest management methods to support game over wood production, and have been willing to sacrifice economic interests to protect wildlife (Hallikainen et al. 2010). Many forest owners are also engaged in hunting, motivating them to practise so called game-friendly forestry.

In Finland, forest grouse species are game animal species. Hunting is based on the principle of sustainable use and strictly regulated through the Hunting Act (615/ 1993 1993) and the Hunting Decree (666/1993 1993), taking into account the size and development of game populations. Government decrees are issued to determine, for example, the maximum limits, areas and temporal restrictions for hunting of game animals, including forest grouse. Regulations are based on continuous game monitoring and estimations of regional population sizes. As regards forest grouse, hunting is governed also by EU legislation (Directive 2009/147/EC 2009). For example, because of declining trend in the population size since 2011 (Fig. 1) hunting of forest grouse species was further restricted (Decree 604/2017 2017). In addition to hunting regulations, game policy is implemented through game management plans which include active measures

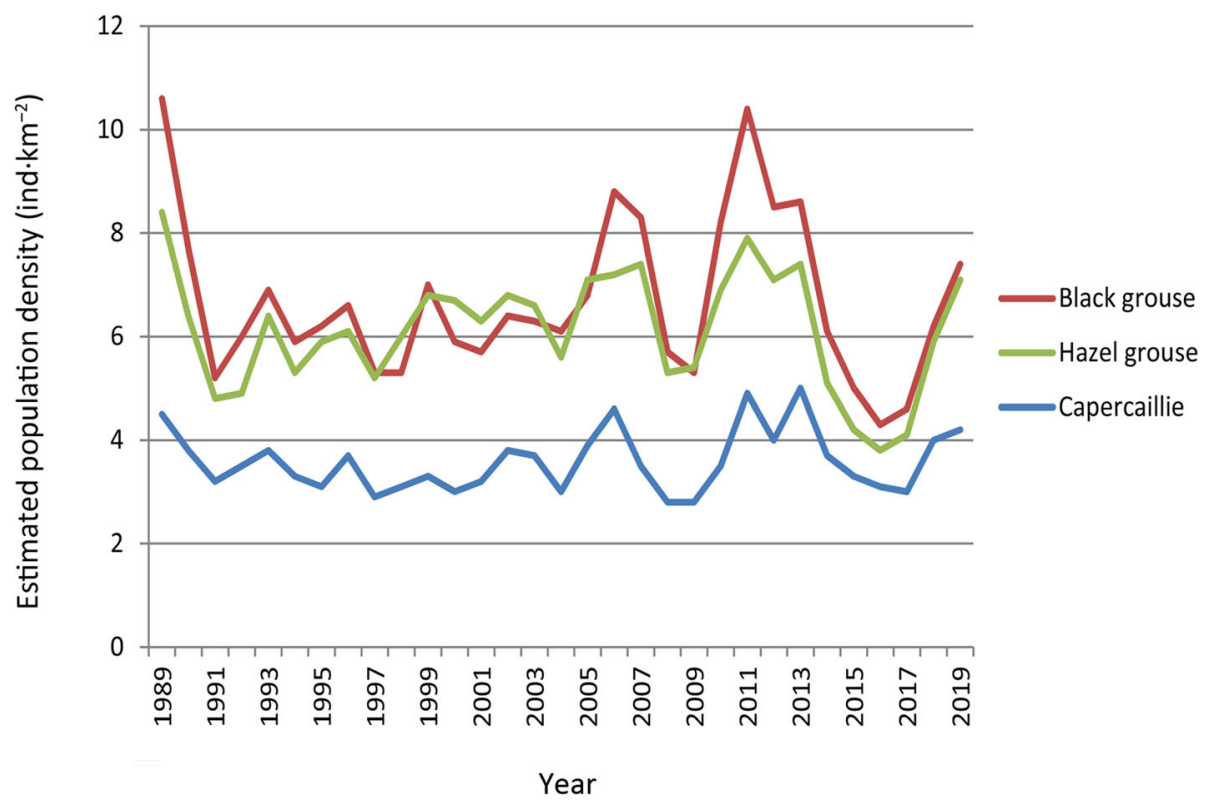

Fig. 1 Estimated population density of forest grouse (individuals per $\mathrm{km}^{2}$ of forest land) in Finland from 1989 to 2018 based on the wildlife census data (http://www.Riistakolmiot.fi, Luonnonvarakeskus (Luke) 2019) 
to increase or preserve game populations and improve their living conditions. The current management plan for forest grouse aims to improve habitats suitable for forest grouse, especially in managed forests (Suomen metsäkanalintukantojen hoitosuunnitelma 2014).

At the regional level where common targets for both wood harvesting and safeguarding of specific habitats are negotiated between stakeholders, analysing the trade-off between forest grouse habitats and wood production can support resource-smart decision making. In Nordic countries, the typical size of a managed forest stand (i.e., a management unit) ranges from 0.5 to 2 ha which is too small to fulfil the habitat requirements for all forest grouse species. An analysis of habitats suitable for grouse should be extended to large landscapes as opposed to single forest stands. Consequently, modelling habitats to determine trade-offs should be based on forest landscape data with full geographic coverage. Large-scale field data is often limited to sample plots, but remotely sensed data such as satellite imagery can produce spatially explicit information on forest characteristics. Recently, airborne light detection and ranging (LiDAR) data has been used to identify structural features of forests and predict species occurrence at the regional level (Graf et al. 2009; Zellweger et al. 2013; Melin et al. 2016).

Trade-off analyses applied to a forestry context for balancing between ecological and economic objectives have been proposed before. According to Chen et al. (2016), commonly used methods include optimization programming, multi-criteria decision analyses, and production possibility frontiers (PPFs). Kangas et al. (2015) presented analytical methods used in decision support for forest management, and Uhde et al. (2015) reviewed multi-criteria decision analyses in more detail. A PPF curve can illustrate the efficient production combinations of two outputs with a given set of inputs and available technology, and provide forest management solutions where the increase in one output necessitates a decrease in the other (Mas-Colell et al. 1995).

In trade-off analyses, ecological provision objectives have been expressed as areas of old forest (Kangas and Pukkala 1996; Carlsson 1999), volume of old deciduous forest (Andersson et al. 2006), and habitat suitability quantified by means of spatially explicit and species-specific habitat models or habitat indexes based on forest structure and landscape characteristics (Arthaud and Rose 1996; Calkin et al. 2002; Nalle et al. 2004; Hurme et al. 2007; Tikkanen et al. 2007; Hauer et al. 2010; Mönkkönen et al. 2014; Kline et al. 2016). Recently, several studies have focused on joint production of multiple ecosystem services by simulating alternative scenarios (Kline et al. 2016; Pukkala 2016; Heinonen et al. 2017; Eggers et al. 2018; Eyvindson et al. 2018) and have incorporated social sustainability into their analyses by evaluating management strategies in a participatory stakeholder process (Nordström et al. 2013; den Herder et al. 2017; Eggers et al. 2018).

Analytical methods for multi-objective forest management planning have been developed to support forest owners in decision making at the forest holding level (see Pukkala 2008; Kangas et al. 2015). Consequently, many trade-off studies have used stand-level forest data and been limited to geographically small areas (e.g., Hurme et al. 2007; Seidl et al. 2007; Pukkala 2016). For policy support at the regional and national scale, studies have resorted to sample plot data of national forest inventories (NFI) (Sievänen et al. 2014; den Herder et al. 2017; Heinonen et al. 2017). However, spatially explicit habitat models for generating ecological values for trade-off analyses require spatial forest data. Stand-level forest data is seldom available or up-to-date and rarely offers full geographic coverage for large areas such as provinces, but remote sensing can provide this data. In Sweden, Eggers et al. (2018) used a country-wide forest stand map based on satellite imagery and field data from NFI (Reese et al. 2003) for balancing diversified management goals at the municipality level. In Finland, Haakana et al. (2017) applied a multi-source national forest inventory (MS-NFI) method based on satellite data and NFI sample plot data (Tomppo et al. 2008) to study the effects of alternative forest management strategies on habitats of the Siberian flying squirrel (Pteromys volans) at the regional level.

In this study, we used the same methodology in scenario modelling as in Haakana et al. (2017) but took it a step further. The results of alternative felling scenarios were constructed as PPFs to evaluate trade-offs between economic and ecological objectives, represented by volume of wood removal and net present value of wood production, and habitat area of forest grouse. PPFs for wood removal and forest grouse habitat were calculated by applying a forestry scenario model, the Finnish MS-NFI, and a joint habitat model of three forest grouse species. Our main objective was to link information on habitat requirements of the species with forestry scenario analyses, and use PPFs to explore the loss of suitable habitat caused by different felling rates and to assess the economic cost of increasing habitat areas. An additional objective was to compare the trade-offs in two regions representing different landscape structures and dependencies on forestry as a livelihood in the area. Scenario results were also compared to levels of recorded (business as usual) wood removal and that envisaged by valid regional forestry programmes, and their sustainability in terms of grouse habitat area was discussed.

\section{Material and methods}

\section{Study areas}

We selected two areas representing two different vegetation zones and landscape structures. The eastern study area covered the province of North Karelia and is 
located within the northern and mid-boreal zones (Fig. 2). In this region, managed forest landscapes are dominated by Scots pine (Pinus sylvestris L.) and Norway spruce (Picea abies (L.) Karst.) with a mixture of deciduous tree species, primarily birch (Betula spp.) and sparse aspen (Populus tremula L.). Open mires, pine mires, peatland forests, and small lakes are common, and agriculture is generally small-scale. Forestry land covered $89 \%$ of the land area in North Karelia (Forest resources 2018). The southern study area comprised the former Forestry Centre of Southwest Finland, largely encompassing two provinces in continental Southwest Finland (Satakunta and Varsinais-Suomi), and was located primarily in the southern boreal zone (Fig. 2). In contrast to the eastern area, large agricultural plots and settlements cover a considerable proportion of the land, and open mires and drained peatland are less common. The proportion of forestry land was $64 \%$ of the land area

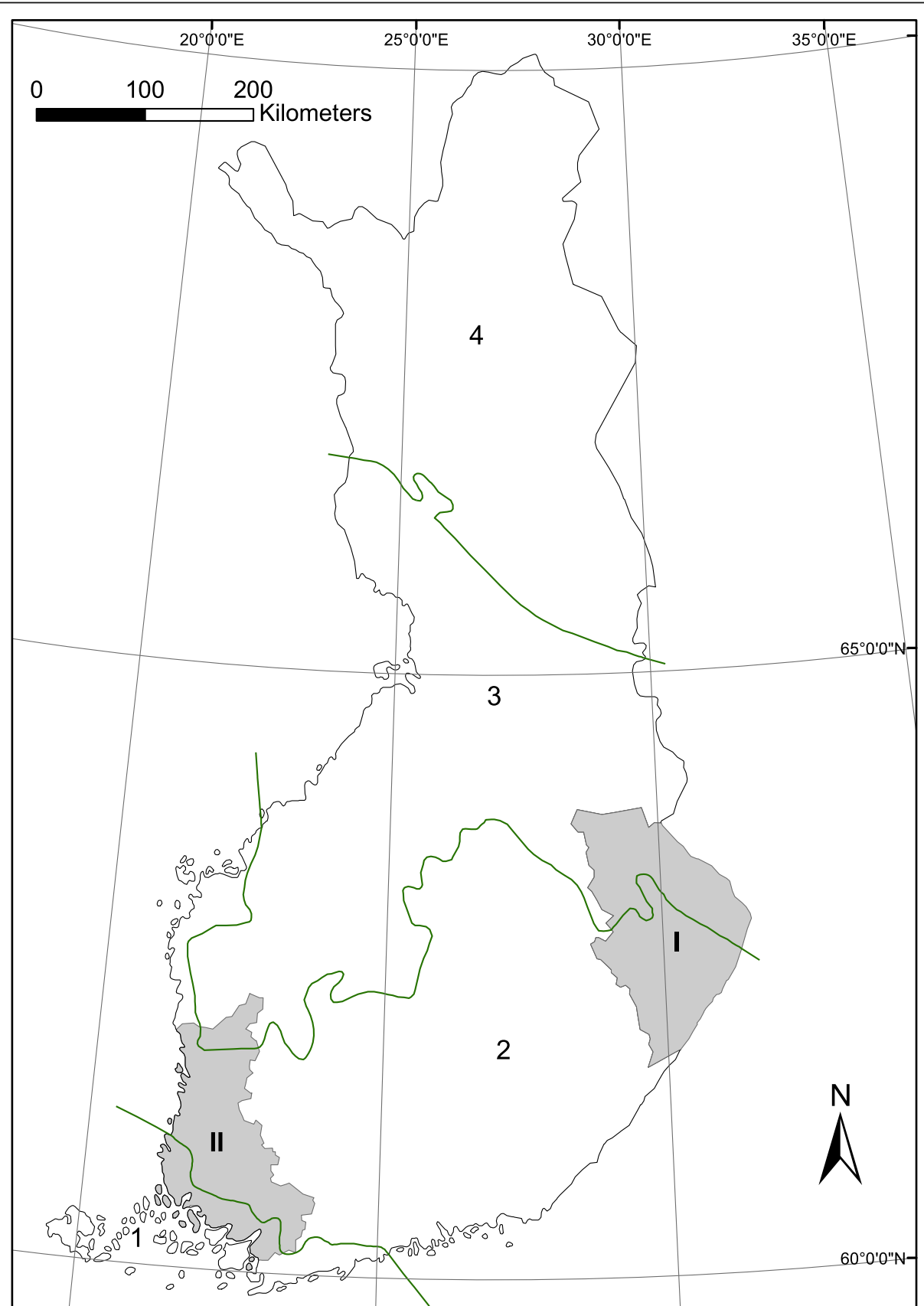

Fig. 2 Locations of the study areas (I: North Karelia and II: Southwest Finland) and vegetation zones: 1 hemi-boreal, 2 southern boreal, 3 middle boreal and 4 northern boreal 
(Forest Resources 2018). In Southwest Finland, the share of privately owned forestry land was higher (79\%) than in North Karelia (53\%) (Forest Resources 2018).

\section{Grouse data}

We used Finnish wildlife census data of tetraonids, known as wildlife triangular census data, conducted from 1997 to 2004 in southern and central Finland. Census data was taken annually from between 66 and 125 wildlife triangles. The basic unit in this nationwide monitoring programme, organized by the Natural Resources Institute Finland and the Finnish Wildlife Agency and conducted by volunteers, is a permanent, $12 \mathrm{~km}$ triangular route (each side is $4 \mathrm{~km}$ in length) that is enumerated twice each year. To ensure the random location of routes, each wildlife triangle is restricted to one topographic map sheet $(10 \mathrm{~km} \times 10 \mathrm{~km})$, and no map sheet contained more than one triangle (Lindén et al. 1996). The shape and considerable large size of a triangle, compared to the size of a map sheet, increase the probability that different forest habitats are well-represented (Helle and Lindström 1991). The special grouse censuses were started already in early 1960's in Finland, first based on line transect sampling (1964-1988) and since 1989 counts on permanent wildlife triangles (Lindén et al. 1996). The census data applied in this study was restricted to the years 1997-2004 as this was available for the research.

Grouse census collections along triangle routes were conducted in mid-August, after the most intensive grouse breeding season (May-July). In this study, we limited our observations to forest grouse species; capercaillie, black grouse, and hazel grouse females with broods. A census of grouse species was taken along a 60 $m$ belt by a chain of three people (Helle and Lindström 1991). The total census area covered by one triangle was $0.72 \mathrm{~km}^{2}$. All observations of grouse broods were marked on a topographic map (1:20,000). A total of 2243 brood observations were made (230-344 per year).

Forest grouse females remain with their brood until at least mid-August, and the wildlife triangle census data yielded a useful variable, namely the occurrence of a grouse hen with a brood, as an index of breeding success (Rajala 1974; Lindén 1981). The index was calculated by determining the sex and age (old or young of the year) of black grouse, capercaillie, and hazel grouse. The recorded index may be an overestimate owing to the lower probability of observations of broodless hens in the census (Brittas and Karlbom 1990), but temporal and spatial analyses of the variable are nonetheless justified. As observations were of the presence of adult grouse females, the habitat was considered suitable for grouse broods.

\section{Landscape data}

We digitized the observations of adult female grouse with broods and imported these observations to a Geographic
Information System (GIS), ArcGIS. Around each observation point, we measured the landscape structure to a radius of $500 \mathrm{~m}$, covering $78.5 \mathrm{ha}$. In addition, a corresponding number of random points were selected, and the same landscape variables were measured around them to the same radius. A random point was situated on forest land at least $1000 \mathrm{~m}$ from a grouse brood observation point to avoid the overlapping of landscape structures. In statistical analyses, the landscape variables associated with the grouse brood observations were contrasted with the corresponding variables around the random points, i.e., background locations or pseudoabsences. The random points provided a comparative data set for constructing a predictive model of the species' occurrence. A radius of $500 \mathrm{~m}$ was selected as the spatial scale for measuring habitat selection by grouse broods, as this included the nest site and home ranges of grouse females and their broods during the summer (e.g., Rolstad et al. 1988; Åberg et al. 1995; Kurki et al. 2000).

The land use and forest resource data was produced by the Multi-Source National Forest Inventory of Finland (MS-NFI) (Tomppo et al. 2009) based on field measurements taken from NFI sample plots in 2004 and 2005, as well as Landsat 5 TM images (from the year 2005) and digital map data from the National Land Survey of Finland. The MS-NFI data included georeferenced raster layers of 20 different forest variables at a resolution of 25 by $25 \mathrm{~m}$. In the estimation of forest variables, digital map data such as roads and agricultural land were used to separate forested land from nonforested land. Satellite image-based MS-NFI data was imported into the GIS and each pixel was reclassified into 11 biologically meaningful habitat classes (Table 1). MS-NFI layers used in the reclassification were the total volume of growing stock $\left(\mathrm{m}^{3} \cdot \mathrm{ha}^{-1}\right)$ and volumes by tree species, largely Scots pine, Norway spruce, birch (Betula pendula Roth and Betula pubescens Ehrh.), and other deciduous trees (mainly aspen and alder (Alnus incana (L.) Moench)) $\left(\mathrm{m}^{3} \cdot \mathrm{ha}^{-1}\right)$. In addition, MS-NFI map data was used to separate peatlands from mineral soils. The distribution of different landscape classes in the two study areas is presented in Table 2. For statistical analyses, the landscape variables were calculated as proportions (\%) of each landscape class (Table 3) within a radius of $500 \mathrm{~m}$ around the grouse brood observation and random points.

\section{Statistical analyses}

We used a multiple logistic regression model when analysing the relationship between forest characteristics and grouse females with broods. We used the presence of a grouse female with a brood as a dependent variable, and the proportions of different landscape classes as independent variables. As most wildlife triangles were investigated 
Table 1 Variables used in modelling and predicting the occurrence of grouse broods on a landscape scale, within a $500 \mathrm{~m}$ radius

\begin{tabular}{|c|c|}
\hline Landscape class & Description \\
\hline Field & Agricultural areas (in map data) \\
\hline Water & Lakes and rivers (in map data) \\
\hline Clear-cut area & Mean volume $\leq 4 \mathrm{~m}^{3} \cdot \mathrm{ha}^{-1}$ and mineral soil, clear-cut or open area with scattered trees \\
\hline Open peatland & Mean volume $\leq 4 \mathrm{~m}^{3} \cdot \mathrm{ha}^{-1}$ and peatland (in map data) \\
\hline Pine mire & Mean volume $\geq 4 \mathrm{~m}^{3} \cdot \mathrm{ha}^{-1}$ and dominated by pine ( $\geq 60 \%$ of volume) and peatland (in map data) \\
\hline Spruce mire & Mean volume $\geq 4 \mathrm{~m}^{3} \cdot \mathrm{ha}^{-1}$ and dominated by spruce ( $\geq 60 \%$ of volume) and peatland (in map data) \\
\hline Young pine forest & Mean volume $>4$ and $\leq 60 \mathrm{~m}^{3} \cdot \mathrm{ha}^{-1}$ and dominated by pine $(\geq 60 \%)$ and mineral soil \\
\hline Pine forest & Mean volume $>60$ and $\leq 150 \mathrm{~m}^{3} \cdot \mathrm{ha}^{-1}$ and dominated by pine $(\geq 60 \%)$ and mineral soil \\
\hline Young spruce forest & Mean volume $>4$ and $\leq 60 \mathrm{~m}^{3} \cdot \mathrm{ha}^{-1}$ and dominated by spruce $(\geq 60 \%)$ and mineral soil \\
\hline Spruce forest & Mean volume $>60$ and $\leq 150 \mathrm{~m}^{3} \cdot \mathrm{ha}^{-1}$ and dominated by spruce $(\geq 60 \%)$ and mineral soil \\
\hline Young mixed forest & Mean volume $>4$ and $\leq 60 \mathrm{~m}^{3} \cdot \mathrm{ha}^{-1}$ and mixed with deciduous trees (pine and spruce $<60 \%$ ) \\
\hline Mixed forest & Mean volume $>60$ and $\leq 150 \mathrm{~m}^{3} \cdot \mathrm{ha}^{-1}$ and mixed with deciduous trees (pine and spruce $<60 \%$ ) \\
\hline Old forest & Mean volume $>150 \mathrm{~m}^{3} \cdot \mathrm{ha}^{-1}$ \\
\hline Built-up areas & Infrastructures, urban areas, buildings and roads (in map data) \\
\hline
\end{tabular}

every study year, the data consisted of repeated observations in the same areas across time. Because there were variations in the numbers of brood observations between the study areas and over different years for separate grouse species, year of observation was included as a fixed factor, as a forced variable in a stepwise model. The year variable was not found to be significant $(P=0.860)$ indicating that there was no year effect, and was excluded from the model. As a final result we obtained forest habitat variables that predicted the probability of grouse brood occurrence in the landscape (Table 4). The overall accuracy of

Table 2 The distribution of landscape classes in the two study areas according to the MS-NFI data in 2005

\begin{tabular}{llllll}
\hline \multirow{2}{*}{ Landscape class } & \multicolumn{2}{l}{ North Karelia } & & \multicolumn{2}{l}{ Southwest Finland } \\
\cline { 2 - 3 } \cline { 6 - 6 } \cline { 6 - 6 } Field & Area (ha) & Percent (\%) & & Area (ha) & Percent (\%) \\
Water & 102,752 & 4.8 & & 425,854 & 19.4 \\
Clear-cut area & 14,526 & 0.7 & & 10,352 & 0.5 \\
Open peatland & 45,987 & 2.1 & & 28,502 & 1.3 \\
Pine mire & 257,247 & 11.9 & & 74,137 & 3.4 \\
Spruce mire & $\mathbf{6 7 6 1}$ & 0.3 & & 1063 & 0.0 \\
Young pine forest & 81,187 & 3.8 & & 101,501 & 4.6 \\
Pine forest & 249,934 & 11.6 & & 185,410 & 8.5 \\
Young spruce forest & 17,854 & 0.8 & & 15,771 & 0.7 \\
Spruce forest & 20,164 & 0.9 & & 16,376 & 0.7 \\
Young mixed forest & 184,423 & 8.5 & & 91,377 & 4.2 \\
Mixed forest & 339,807 & 15.7 & & 185,844 & 8.5 \\
Old forest & 355,834 & 16.5 & & 413,347 & 18.9 \\
Built-up areas & $\mathbf{1 0 0 , 2 2 4}$ & 4.6 & & 154,306 & 7.0 \\
Total & $\mathbf{2 , 1 5 9 , 3 9 1}$ & $\mathbf{1 0 0 . 0}$ & $\mathbf{2 , 1 8 9 , 8 2 1}$ & $\mathbf{1 0 0 . 0}$ \\
\hline
\end{tabular}

the model according to the proportion of correctly classified observations in the modelling data was $56.1 \%$, i.e., the whole material was used both for model estimation and testing. The constructed model was used for predicting suitable grouse habitats in forest scenario analyses.

\section{Modelling forest scenarios}

The MS-NFI approach was also utilized in the estimation of initial forest data for scenario analyses using the Finnish forestry dynamics model MELA (Siitonen et al. 1996; Redsven et al. 2007). First, by means of Landsat 5 TM images, map data, and NFI sample plot data, forest

Table 3 Descriptive statistics of the forest habitat variables (\% of the area) measured at a radius of $500 \mathrm{~m}$ around the grouse observation points $(N=2243)$

\begin{tabular}{lllll}
\hline Landscape class & Mean & Std. Dev. & Min & Max \\
\hline Field & 3.71 & 7.89 & 0.00 & 62.03 \\
Water & 1.38 & 3.96 & 0.00 & 39.95 \\
Clear-cut area & 0.61 & 0.96 & 0.00 & 14.48 \\
Open peatland & 1.53 & 4.00 & 0.00 & 69.07 \\
Pine mire & 18.32 & 16.37 & 0.00 & 91.46 \\
Spruce mire & 0.79 & 1.59 & 0.00 & 30.3 \\
Young pine forest & 3.93 & 3.50 & 0.00 & 27.53 \\
Pine forest & 10.79 & 6.96 & 0.00 & 50.79 \\
Young spruce forest & 0.61 & 0.99 & 0.00 & 13.05 \\
Spruce forest & 0.70 & 1.00 & 0.00 & 6.33 \\
Young mixed forest & 6.30 & 4.93 & 0.00 & 51.04 \\
Mixed forest & 16,93 & 7,48 & 0,48 & 67,16 \\
Old forest & 31.62 & 15.16 & 0.24 & 85.44 \\
Built-up areas & 2.78 & 3.27 & 0.00 & 50.08 \\
\hline
\end{tabular}


Table 4 The multiple logistic regression-based likelihoods for grouse broods in relation to forest habitat variables measured at a radius of $500 \mathrm{~m}$ spatial scale. The model fit was $X^{2}=125.6$, $\mathrm{df}=4, P<0.001$

\begin{tabular}{llllll}
\hline Independent variable & Coefficient & S.E. & Wald & df & $P$ \\
\hline Intercept & -1.106 & 0.207 & 28.653 & 1 & $<0.001$ \\
Mixed forest (\%) & 1.850 & 0.313 & 35.013 & 1 & $<0.001$ \\
Old forest (\%) & 0.853 & 0.189 & 20.338 & 1 & $<0.001$ \\
Pine forest (\%) & 0.633 & 0.273 & 5.383 & 1 & $<0.05$ \\
Spruce forest (\%) & -5.168 & 0.574 & 81.093 & 1 & $<0.001$ \\
\hline
\end{tabular}

characteristics for the management units were estimated using the $k$ nearest neighbour method (Haakana et al. 2017). Image segments derived from satellite images approximating forest stands and a combination of similar forest stands in terms of spectral properties served as management units. Administrative land use constraints were taken into account by separating management units in protected forests (i.e., national parks and nature conservation areas), and in other areas where forest management was restricted, from those in managed forests. In the MELA analyses, each management unit was represented by a set of NFI sample plots (Mäkelä et al. 2011).

In the MELA system, a stand simulator based on individual tree level models was used to produce a large number of feasible management schedules for each management unit, and thereafter, an optimisation package (Lappi 1992) was used to simultaneously select a production programme for the whole forest area and corresponding management schedules for all management units. In this study, five alternative forest scenarios in terms of wood removal over a 60-year planning period were compiled separately for both study areas. The simulation time was divided into 6 ten-year sub-periods, for which forest management activities were simulated in the middle of the sub-periods. The results were reported for the first five sub-periods and the sixth sub-period was used only to ensure sustainability of wood production after the 50-year period. Management activities included thinnings based either on number of trees or on basal area, regeneration fellings (clear cutting, seed tree cutting or shelterwood cutting), clearing of regeneration areas, soil preparation, artificial regeneration of pine, spruce or birch, and tending of young stands (see Redsven et al. 2007). Simulated management schedules were based on development models designed for Finnish conditions (see Hynynen et al. 2002) and aligned with management practice recommendations (Hyvän metsänhoidon suositukset 2006). The management practice recommendations defined the guidelines for the details of the activities, for example, the minimum basal area requirements before and after thinnings, and the minimum rotation periods in terms of biological age and mean diameter. For each regeneration and intermediate felling activity, a no-treatment alternative was also simulated. As a consequence of this, the felling activities could also be postponed and simulated in the subsequent sub-periods as alternative management schedules. Clearing of regeneration area, soil preparation, artificial regeneration and tending of young stands were treated as obligatory activities and they could not be postponed. Unit costs and revenues were as used by Nuutinen and Hirvelä (2006). Protected forests were not included in wood production.

In all five scenarios, the net present value from wood production was maximised using a $4 \%$ interest rate. The $4 \%$ interest rate has been commonly used in the forestry scenario analyses of maximum sustainable removal in Finland (e.g., Nuutinen et al. 2000; Salminen et al. 2013; MELA Summary Report 2018). In the first scenario, known as the scenario of maximum sustainable wood removal, the net present value from wood production was maximized with constraints demanding a sustainable flow of wood removal, saw log removal, and net income over the 60-year period. In the second, third, and fourth scenarios, the same constraints were applied, but the level of wood removal was set as $75 \%, 50 \%$, or $25 \%$ of the level of removal in the first scenario, respectively. In the fifth scenario, no regeneration or intermediate felling were applied, to indicate no wood removal over the 60year planning period. In all scenarios, ecological and social objectives were taken into account when simulating management for units. Forest conservation areas were completely set aside from all management activities and clear felling was not allowed on units in restricted use. Further, as stated in the recommendations for forest management practises (Hyvän metsänhoidon suositukset 2006), simulation accounted for, for example, retention trees on clearcutting sites.

\section{Predicting grouse habitats in the forest scenarios}

The grouse occurrence model was applied using the estimated MELA forest data for 2005 and 2055, simulated according to the five felling scenarios. Forest variables required for the formulation of the explanatory variables (total volume of growing stock and volume by tree species) were assigned to each management unit (image segment), and these were output as raster maps. The average size of the segments was 1.34 ha in North Karelia and 1.17 ha in Southwest Finland. The model was applied at points along a regular one-kilometre grid over the study areas. Forest data was reclassified (Table 1) and landscape scale variables (pencent of area) within a buffer zone of $500 \mathrm{~m}$ around points were calculated and used for prediction. If the predicted probability of occurrence was greater than or equal to 0.5 , the point was interpreted as a suitable grouse habitat. Areas of suitable 
habitat in each scenario were calculated for the study areas, and effects of different felling levels were analysed.

\section{Results}

The estimated area of forestry land in North Karelia was 1.57 million ha and the total volume of growing stock was 167.7 million $\mathrm{m}^{3}$ at the beginning of the simulation period (2005), of which $97 \%$ was available for wood production. The estimates for Southwest Finland were 1.12 million ha and 140.7 million $\mathrm{m}^{3}$ (99\%), respectively. The development of growing stock in the different scenarios depended upon the level of felling (Fig. 3a and b). With regards to tree species structures of growing stock and wood removal, pine was dominant in both study areas in their current state, and its share of the removal was also largest during the first decades of the simulation period for all scenarios. In North Karelia, forests remained pinedominated, but in Southwest Finland, the proportion of spruce increased towards the end of the simulated study period, accounting for the largest proportion $(44 \%-53 \%)$ of standing volume in 2055 in all scenarios except in the 0 and $25 \%$ scenarios, where pine remained dominant (44\%).

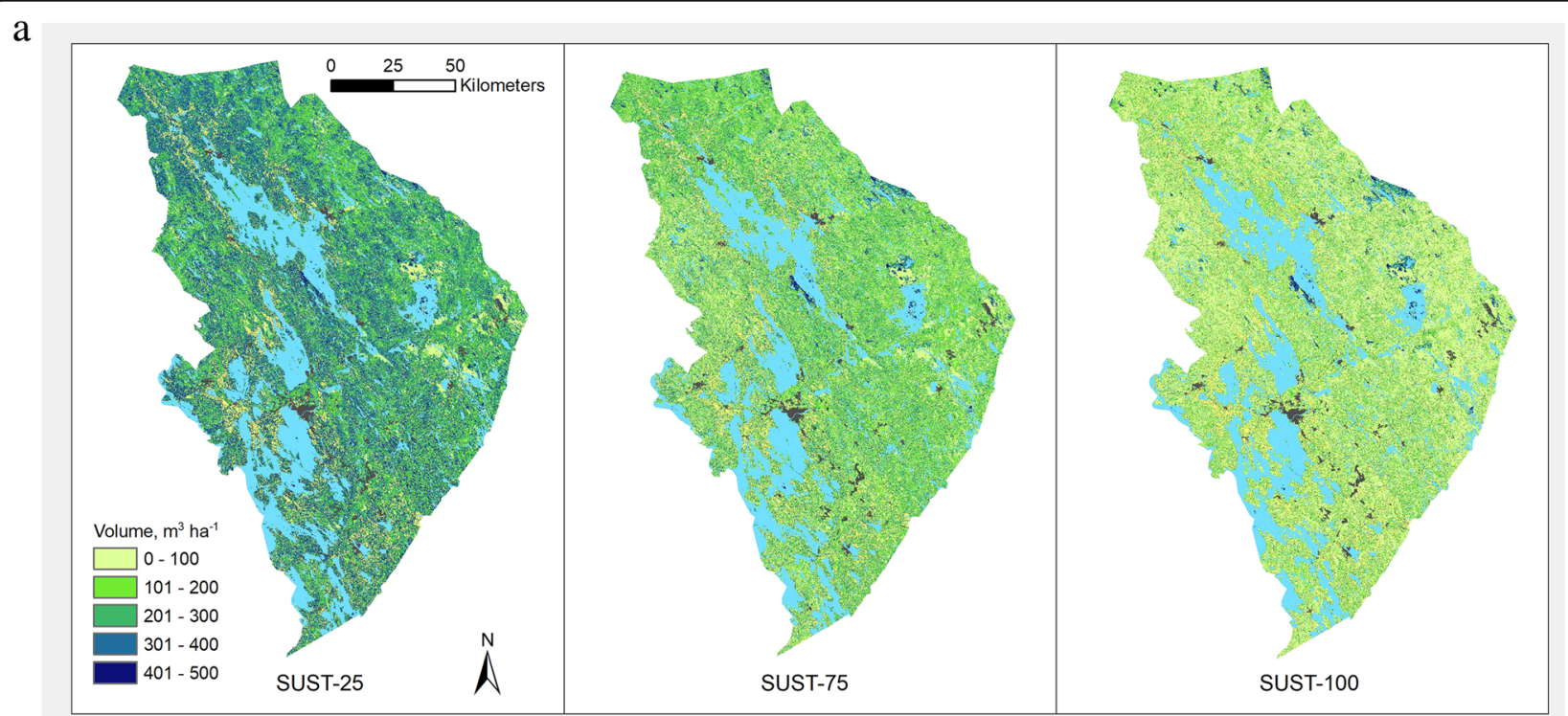

b

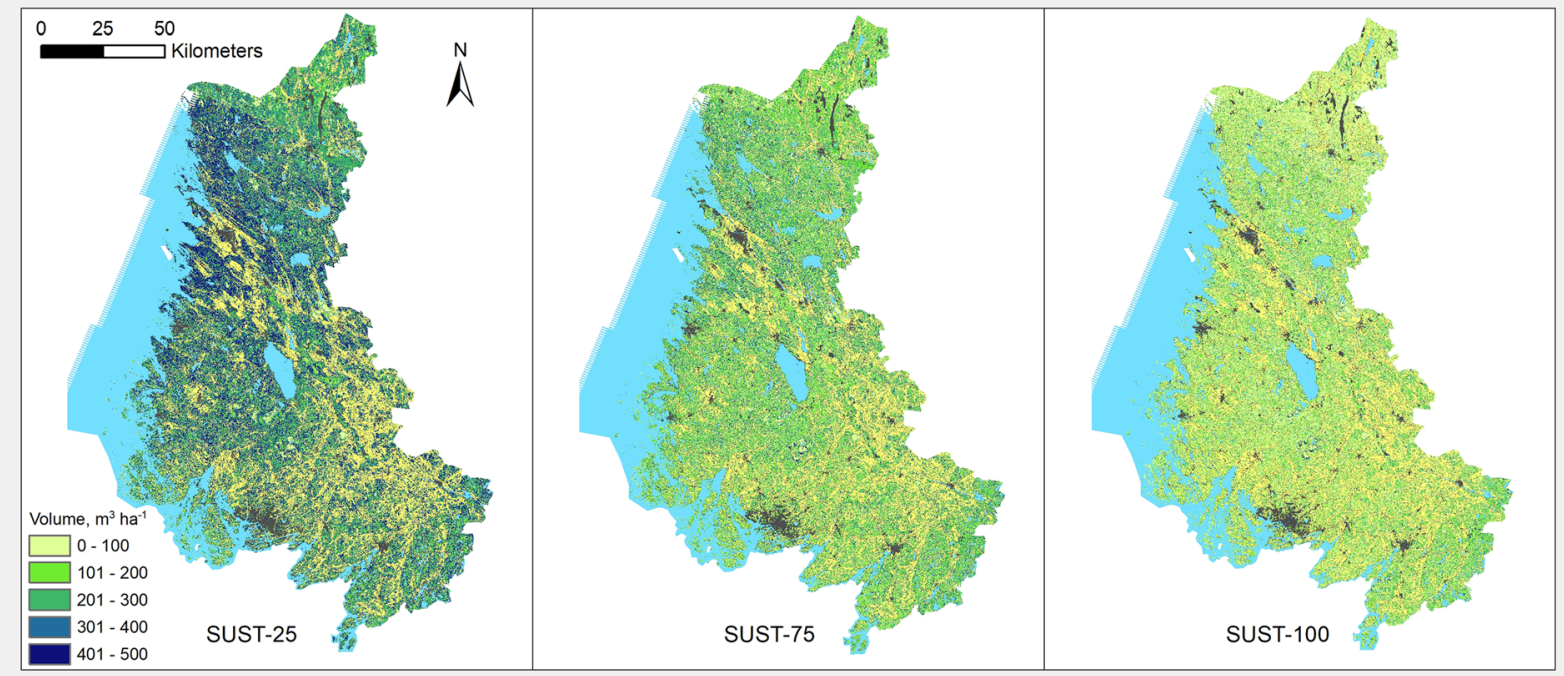

Fig. 3 The estimated volume of growing stock in (a) North Karelia and (b) Southwest Finland in 2055 according to the scenario of maximum sustainable wood removal (SUST) with different felling levels (25\%, 75\%, and 100\%). Map colours: yellow - agricultural land, blue - water, grey built-up areas, and green - forestry land; the darker the shade, the higher the volume. Digital map data: National Land Survey of Finland 2008 
In North Karelia, the scenario of maximum sustainable wood removal resulted in a removal of 7.0 million $\mathrm{m}^{3}$ per year (Fig. 4), and a net income of 247.1 million euros per year by the end of the study period (2045-2054), while felling potential was 11.7 million $\mathrm{m}^{3}$ per year. The felling potential is the maximum removal that can be harvested if the profitability and sustainability of the fellings are ignored and only the management practice recommendations (Hyvän metsänhoidon suositukset 2006) are used as guidelines. Removal included saw logs and pulpwood, but not energy wood. The proportion of saw log removal was $53 \%$; this increased in scenarios with lower levels of felling and was highest (59\%) in the $25 \%$ level scenario. The $75 \%$ level scenario resulted in the removal of 5.2 million $\mathrm{m}^{3}$ per year which matched levels recorded from 2012 to 2014 (Official Statistics of Finland (OSF) 2018). For reference, the goal of the valid regional forestry programme of North Karelia is to increase felling up to 6.6 million $\mathrm{m}^{3}$ per year by 2020 (Metsäkeskus 2016a). Recorded and targeted removals also only included saw log wood and pulpwood removals.

In the scenario of maximum sustainable wood removal in Southwest Finland, felling potential was 8.4 million $\mathrm{m}^{3}$ per year by the end of the study period (2045-2054); removal amounted to 5.9 million $\mathrm{m}^{3}$ per year, of which
$43 \%$ were saw logs (Fig. 5). The proportion of saw log removal was again highest (59\%) in the $25 \%$ level scenario. Compared to the recorded felling level in Southwest Finland, which amounted to 3.5 million $\mathrm{m}^{3}$ per year from 2012 to 2014 (Official Statistics of Finland (OSF) 2018), the 50\% level scenario came the closest, resulting in the removal of 2.9 million $\mathrm{m}^{3}$ per year. The goal set for 2020 in the valid regional forestry programme for the two provinces in southwestern Finland was 5.0 million $\mathrm{m}^{3}$ per year (Metsäkeskus 2016b), which is $14 \%$ higher than the removal calculated for the $75 \%$ level scenario ( 4.4 million $\mathrm{m}^{3}$ per year). The actual provinces do cover a slightly different area than the study area of Southwest Finland, however, and also include part of the archipelago south of the study area.

In both study areas, the predicted amount of potential forest grouse habitat in 2055 gradually decreased as intensity of felling increased (Figs. 4 and 5). Under the scenario of maximum sustainable wood removal, the predicted habitat area was $22 \%$ smaller than under the no removal scenario in North Karelia, whereas in Southwest Finland the decrease was more pronounced at 55\%. The 75\% felling levels reduced predicted habitat areas by $10 \%$ and $24 \%$, respectively. The predicted amount of forest grouse habitat in 2055 under the scenario of maximum

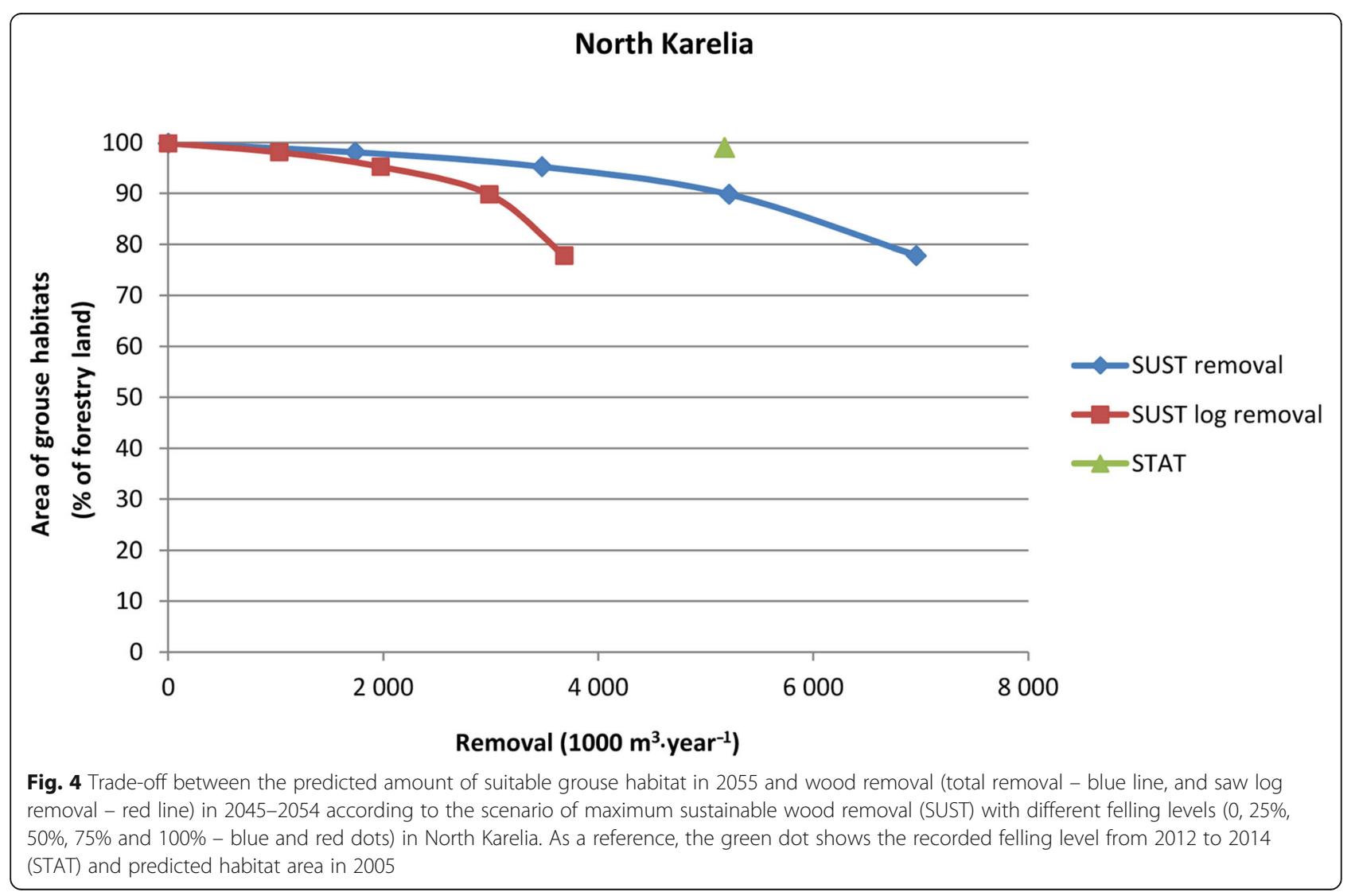




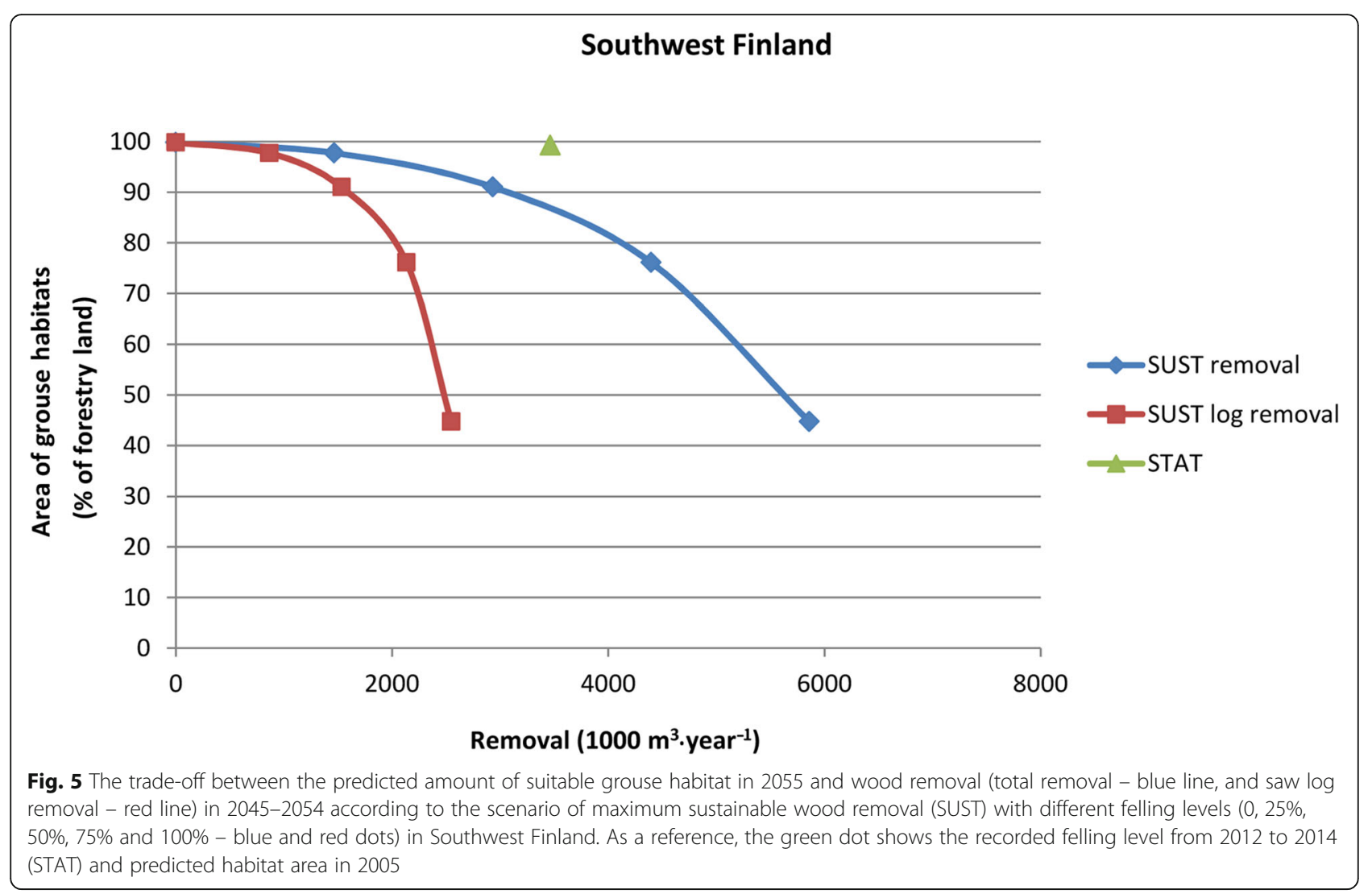

sustainable removal was $78 \%$ of the total forestry land area in North Karelia and 45\% in Southwest Finland. The opportunity costs of increasing the area of forest grouse habitat measured with the net present value of wood production are shown in Fig. 6. No felling (0\%) scenarios resulted in negative net present values, signifying no income from wood harvesting to offset management costs, for example, due to tending of young stands.

\section{Discussion}

PPFs were effective tools to explore case-specific tradeoffs between wood production and forest grouse habitat areas. In North Karelia, the $75 \%$ level of maximum sustainable wood removal, which also corresponded to recent levels of recorded felling (Official Statistics of Finland (OSF) 2018), resulted in a mere $10 \%$ loss of habitat area. Even in the scenario of maximum sustainable wood removal, reduction of the habitat area was moderate $(22 \%)$ compared to the non-felling scenario. The proportion of forest in North Karelia is $84 \%$ of the total land area, and results suggest that the amount of suitable habitat for forest grouse will not decline dramatically if the forests are managed sustainably and the amount of deforestation is kept to a minimum. In Southwest Finland, habitat reduction was more pronounced as wood removal increased. The scenario of maximum sustainable wood removal reduced the habitat by $55 \%$ compared to the no felling scenario. This could be explained by the fact that forests in Southwest Finland are more fragmented by other land use than in North Karelia. Low forest cover causes the changes in forest structure due to increased felling to have a stronger impact on suitable habitat area. Recorded wood removal in Southwest Finland (Official Statistics of Finland (OSF) 2018) was comparable to wood removal in the $50 \%$ level scenario, which also demonstrates the differences between the regions in terms of forestry as a means of livelihood.

The scenario of maximum sustainable removal reflected an intensive felling scenario where the felling potential was maximally utilized taking into account logging profitability and sustainability assuming a nondecreasing flow of wood removal, saw log removal, and net income over the 60-year study period. In both study areas, recorded felling levels (Official Statistics of Finland (OSF) 2018) have been lower than estimated maximums for sustainable wood removal (MELA Summary Report 2018). It should also be noted that the use of newer NFI data in the scenario analyses could have resulted in different removal amounts. 


\section{Opportunity costs}

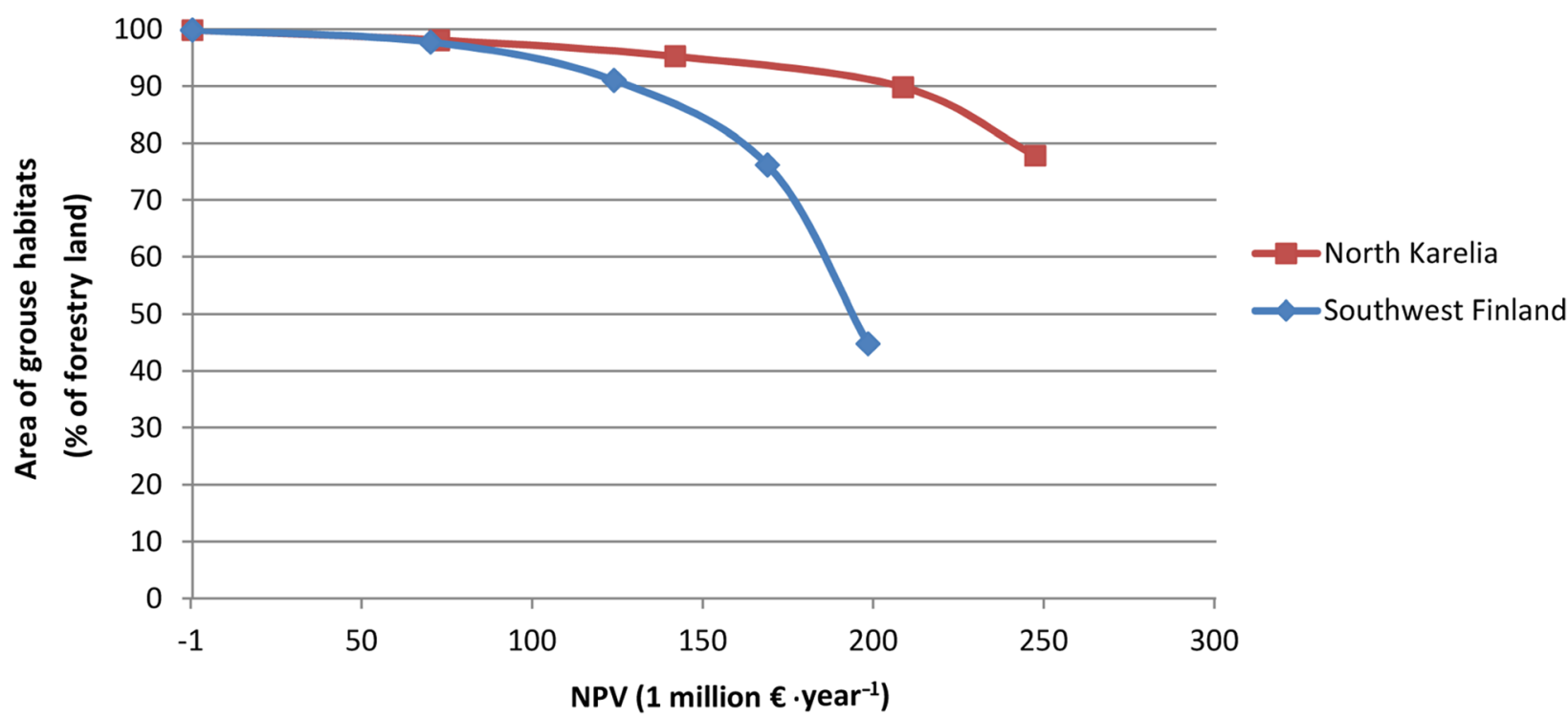

Fig. 6 Opportunity cost of increasing the habitat area suitable for forest grouse, measured by the net present value of wood production (NPV) in 2045-2054 according to the scenario of maximum sustainable wood removal with different felling levels (0,25\%, 50\%, 75\% and 100\% - blue and red dots) in the two study areas

The fact that the proportion of saw log removal was higher in the scenarios with lower felling rates (Figs. 4 and 5) indicates that felling is first carried out for the most economically viable forest stands, that is, stands with higher volumes or higher percentage of saw logs, to fulfil the objective of maximizing net present value in the optimization phase. The proportion of wood removal from regeneration felling compared to that from intermediate felling, however, increased alongside increased felling levels. Consequently, scenarios with an increased amount of regeneration felling to include clear-cut areas and seeding stands demonstrated a negative effect on suitable grouse habitats.

The tree species structure of growing stock changed over the 50-year period, particularly in Southwest Finland, where the proportion of spruce volume increased towards the end of the simulation period in all scenarios. In addition to the more fragmented landscapes, another reason for the greater loss of grouse habitat in Southwest Finland was that, according to our model, spruce dominated forests were less favourable to forest grouse. NFI results also show an increasing trend towards spruce dominated forests in South Finland (Korhonen et al. 2017). Until the 1990s, pine was most favoured for planting, even on fertile sites, but currently spruce is the dominant tree species in young forests (Korhonen et al. 2017).

Scenario results were logical, although the grouse occurrence model did not perform as expected. Nearly all the forestry land was predicted to be suitable grouse habitat at the beginning of the simulation period (2005) and in the scenario of no felling in 2055. One reason for this could be that the model combined habitat preferences for three forest grouse species. Of these, the capercaillie most strictly favours old coniferous forest, whereas black grouse and hazel grouse favour younger forests (Rolstad 1989; Kurki et al. 2000; Åberg et al. 2003; Miettinen et al. 2010). Because of this, the occurrence model included a wider forest habitat pool than if we had used habitat preferences for a single species. The high amount of suitable habitat also suggests that the threshold of 0.5 used for transforming the predicted probability of occurrence into habitat suitability may not have been optimal (Pearce and Ferrier 2000). As the occurrence data lacked information on true absences, model predictions should be treated with a certain amount of caution (Pearce and Boyce 2006). Because the random absence locations were not searched for the species, some of these locations might actually represent presence locations (Keating and Cherry 2004). Inclusion of these false absences may substantially bias analyses (Hirzel et al. 2002). In addition, because of sampling the same number of random absence locations as presence locations, the proportion of presences may not represent the true prevalence of the species (Pearce and Boyce 2006).

The model was based on the MS-NFI forest data estimated using the $k$ nearest neighbour method, which is known to lead to averaged and potentially biased estimates 
(Altman 1992; Nilsson 1997; Katila and Tomppo 2001). This may have affected the prediction results; the volume thresholds used in reclassifying landscape classes could have led to the overestimation of suitable habitats. Estimated volumes by tree species in the MS-NFI data are not accurate at pixel level (Katila and Tomppo 2001), which in turn confuses the separation of pine, spruce, and mixed forests used as explanatory variables in the model. We assume that the suitable habitat area was overestimated primarily due to different forest data used in fitting and applying the model; MS-NFI volumes at pixel level were used as modelling data, whereas NFI sample plot measurements and simulations were based on tree level data averaged for the segments in predicting occurrences over the study areas. However, the model did enable the calculation of PPFs and an exploration of the trade-offs between felling levels and forest grouse habitats.

It should also be noted that the selection of simulated management activities for the management units were optimised for the regional scale, and consequently, the locations of these activities were arbitrary. Forest ownership or adjacent management units and their management activities were not taken into account in felling allocations. Hence, the PPFs as described herein can support strategic planning only at the regional level; they can be used to estimate the loss of raw material to the forest industry in favour of forest grouse habitats. In addition, the opportunity cost of increasing grouse habitat area could be estimated in the form of reduced net income from wood production for forest owners. For that purpose, the evaluation of trade-offs could be improved by applying a monetary value to grouse habitats, by including hunting, recreation, and biodiversity value. Management options applied to continuous cover forestry (single-tree and patch logging) could also be included in the set of alternative management practises in forest dynamics models. Currently in MELA, continuous cover forestry can be simulated only, for example, with prolonged rotations and regulation of the level of thinning.

The grouse occurrence model confirmed that the area of old-coniferous mixed forest is important for the grouse species. This pattern was most likely due to the availability of a rich canopy and understory cover along with better food resources for broods in the old mixed forests (Miettinen et al. 2008, 2010; Melin et al. 2016). Blueberries play an especially important role in the ecology of forest grouse broods (Storch 1993; Baines et al. 2004). At the forest stand scale, grouse broods need stands rich in deciduous trees, with good canopy and ground cover to provide food and shelter. These characteristics also appear in younger forests and may have confused the modelling because the forest classes known to have negative effects on grouse occurrences, such as clear-cut areas and seedlings, were not included as explanatory variables in the model. It has been found that on mineral soils the cover provided by blueberry bushes increases with forest stand age and basal area and decreases strongly during regeneration cuttings (Tonteri et al. 2016; Turtiainen et al. 2016; Nilsson and Cory 2017). Because recently regenerated stands have lower understory cover and higher predation risks, grouse brood survival is better in old forest stands (Kastdalen and Wegge 1985; Moss and Oswald 1985; Miettinen et al. 2010; Melin et al. 2016).

At the landscape scale, both habitat loss and fragmentation are considered to have negative effects on animal population persistence (Wilcox and Murphy 1985; Trzcinski et al. 1999). Land-use shifts from forest to other uses in addition to felling can make the landscape less suitable for forest grouse. In southern agricultural landscapes, forests are more permanently fragmented than in northern managed forest landscapes. In a previous study it has been shown that forest habitat loss is more important than habitat fragmentation for grouse broods (Huhta et al. 2017). However, forest fragmentation might not be totally meaningless since grouse broods were less numerous in the areas with high densities of forest-open land edges (Huhta et al. 2017).

An increase in open fields or clear-cut areas and young successional forest stages tends to sustain populations of potential grouse nest predators (Wegge et al. 1990; Kurki and Lindén 1995; Kurki et al. 2000). The decline in grouse breeding success is commonly associated with elevated rates of nest predation, particularly from mammalian predators (Marcström et al. 1988; Caizergues and Ellison 1997; Kurki et al. 1997, 1998; Kauhala and Helle 2002). Nest predation patterns in a boreal forest landscape are affected by the population cycles of microtine rodents living in open habitats, which in turn affect numbers and habitat use of small- and medium-sized predators (Angelstam et al. 1984; Lindén 1988; Lindström et al. 1995).

Concerning so called game-friendly forest management, forest grouse would benefit from increasing overall forest area with characteristics (old pine-dominated, mixed forests) beneficial for the species. Spatial distribution of the habitat, however, is important as well. The spatial data allowed the use of a landscape-level occurrence model in which the characteristics of the surrounding 78.5 ha were considered. However, the regional approach failed to properly address two important factors for suitable grouse habitats, namely patch size and connectivity. Because the average size of management units was just over $1.0 \mathrm{ha}$, the simulation of the felling was based purely on current growing stock, and there were no constraints on the habitat area, optimization led to fragmentation. In practice, neighbouring stands are generally taken into consideration in management planning. For example, the approach did not allow the combining of neighbouring units or concentration of old 
forest in areas where suitable habitats already exist, with an exception of protected forests, where only ingrowth, growth, and mortality (but no management activities) were simulated. Hence, to study game-oriented forest management on a local level, different optimization techniques such as heuristic optimization and spatial objectives should be applied. This would help in realizing solutions that maximize wood production while minimizing impacts on forest grouse habitats.

\section{Conclusions}

Tetraonids have experienced significant population declines in Fennoscandia during recent decades. Land-use shifts and forest management practices with their diverse ecological consequences have been implicated in these declines. More specifically, the area of old forests with adequate food and shelter for forest grouses has been reduced (Kardell 1980; Atlegrim and Sjöberg 1995; Uotila and Kouki 2005; Kvasnes and Storaas 2007). For this reason, there is an urgent need to safeguard forest grouse habitats and develop grouse-friendly forest management practices. Our occurrence model confirmed that forest grouse prefer old, mixed, and pine dominated forests. These characteristics could be enhanced by forest owners when making decisions on forest management.

At the regional level, forest grouse would benefit from sacrificing part of the sustainable wood removal and limiting the amount of felling, for example, to the $75 \%$ or $50 \%$ level as demonstrated in our study areas. Of note, these levels correspond to recorded felling which has been less than the estimated maximum sustainable wood removal in recent decades. The reduction of suitable habitat area by increasing felling varied according to current forest and landscape structures. In the region where forested area was smaller and more fragmented, the negative effect of increased felling level was more pronounced than in the more heavily forested region. The two study areas also differed in the importance of forestry as a livelihood, measured by different levels of recorded and targeted wood removals in each region.

The study utilized two nationwide data sources, Finnish wildlife triangle census data and MS-NFI data on forest resources. Integrating them with the Finnish forestry dynamics model MELA allowed us to explore trade-offs between wood production and grouse habitats. The PPFs calculated in this study support the evaluation of the loss of suitable habitat reflected by different felling rates, as well as the economic cost of increasing habitat areas. Our approach is suitable for regional analyses, but not as such for operational management planning at the stand level, where it is important to take into account information on adjacent stands in the optimization phase when selecting different management schedules. In this study, spatially explicit objectives or constraints for grouse habitats were not used.

\section{Acknowledgements}

We want to thank the NFI staff of the Natural Resources Institute Finland (until 1, January 2015 the Finnish Forest Research Institute) who have contributed to the NFI and MS-NFI materials applied in this study. We would also like to thank the voluntary hunters who contributed to our study by performing grouse counts. We would further like to thank the anonymous referees for their valuable comments on the manuscript.

\section{Authors' contributions}

All authors participated in study design. Huhta constructed the habitat model and Hirvelä conducted simulations. Haakana prepared forest data for simulations, applied the model for predictions and constructed the production possibilities frontiers. All authors participated in the writing of the manuscript. The author(s) read and approved the final manuscript.

\section{Funding}

Not applicable.

\section{Availability of data and materials}

The datasets generated and analysed during the current study are available from the corresponding author on reasonable request. The original datasets are not publicly available due to restrictions concerning locational information.

Ethics approval and consent to participate

Not applicable.

\section{Consent for publication}

Not applicable.

\section{Competing interests}

The authors declare that they have no competing interests.

\section{Author details}

${ }^{1}$ Natural Resources Institute Finland (Luke), PO Box 2, Fl-00791 Helsinki, Finland. ${ }^{2}$ Natural Resources Institute Finland (Luke), PO Box 16, FI-96301 Rovaniemi, Finland. ${ }^{3}$ Natural Resources Institute Finland (Luke), PO Box 68, Fl-80101 Joensuu, Finland.

Received: 29 April 2019 Accepted: 10 March 2020

Published online: 08 April 2020

\section{References}

Åberg J, Jansson G, Swenson JE, Angelstam P (1995) The effect of matrix on the occurrence of hazel grouse (Bonasa bonasia) in isolated habitat fragments. Oecologia 103:265-269. https://doi.org/10.1007/BF00328613

Åberg J, Swenson JE, Angelstam P (2003) The habitat requirements of hazel grouse (Bonasa bonasia) in managed boreal forest and applicability of forest stand descriptions as a tool to identify suitable patches. For Ecol Manag 175: 437-444. https://doi.org/10.1016/S0378-1127(02)00144-5

Altman N (1992) Introduction to kernel and nearest-neighbour nonparametric regression. Am Stat 46(3):175-184. https://doi.org/10.2307/2685209

Andersson M, Sallnäs O, Carlsson M (2006) A landscape perspective on differentiated management for production of timber and nature conservation values. For Policy Econ 9:153-161. https://doi.org/10.1016/j. forpol.2005.04.002

Andrén H (1994) Effects of habitat fragmentation on birds and mammals in landscapes with different proportions of suitable habitat: a review. Oikos 71: 355-366. https://doi.org/10.2307/3545823

Andrén H (1995) Effects of landscape composition on predation rates at habitat edges. In: Hansson L, Fahrig L, Merriam G (eds) Mosaic landscapes and ecological processes. Chapman and Hall, London, pp 225-255

Angelstam P (1992) Conservation of communities - the importance of edges, surroundings and landscape mosaic structure. In: Hansson L (ed) Ecological principles of nature conservation. Elsevier Applied Science, London. https:// doi.org/10.1007/978-1-4615-3524-9_2 
Angelstam $P$, Lindström E, Widén P (1984) Role of predation in short-term fluctuations of some birds and mammals in Fennoscandia. Oecologia 62: 199-208 http://www.jstor.org/stable/4217304. Accessed 29 Apr 2019

Arthaud GJ, Rose DW (1996) A methodology for estimating production possibility frontiers for wildlife habitat and timber value at the landscape level. Can J For Res 26:2191-2200. https://doi.org/10.1139/×26-248

Atlegrim O, Sjöberg K (1995) Lepidoptera larvae as food for capercaillie chicks (tetrao urogallus): a field experiment. Scan J For Res 10:278-283. https://doi. org/10.1080/02827589509382894

Baines D, Moss R, Dugan D (2004) Capercaillie breeding success in relation to forest habitat and predator abundance. J Appl Ecol 41:59-71. https://doi.org/ 10.1111/j.1365-2664.2004.00875.x

Brittas R, Karlbom M (1990) A field evaluation of the Finnish 3-man chain: a method for estimating forest grouse numbers and habitat use. Ornis Fenn 67:18-23

Caizergues A, Ellison LN (1997) Survival of black grouse Tetrao tetrix in the French Alps. Wildl Biol 3:177-186

Calkin DE, Montgomery CA, Schumaker NH, Polasky S, Arthur JL, Nalle DJ (2002) Developing a production possibility set of wildlife species persistence and timber harvest value. Can J For Res 32:1329-1342. https:/doi.org/10.1139/X02-056

Carlsson M (1999) A method for integrated planning of timber production and biodiversity: a case study. Can J For Res 29:1183-1191. https://doi.org/10. 1139/x99-058

Chen S, Shahi C, Chen HYH (2016) Economic and ecological trade-off analysis of forest ecosystems: options for boreal forests. Environ Rev 24:348-361. https:// doi.org/10.1139/er-2015-0090

Decree 604/2017 (2017) Ministry of Agriculture and Forestry. https://www.finlex.fi/ fi/laki/alkup/2017/20170604 (in Finnish) Accessed 7 Aug 2019

den Herder M, Kurttila M, Leskinen P, Lindner M, Haatanen A, Sironen S, Salminen O, Juusti V, Holma A (2017) Is enhanced biodiversity protection conflicting with ambitious bioenergy targets in eastern Finland? J Environ Manag 187: 54-62. https://doi.org/10.1016/j.jenvman.2016.10.065

Eggers J, Holmgren S, Nordström E-M, Lämås T, Lind T, Öhman K (2018) Balancing different forest values: evaluation of forest management scenarios in a multi-criteria decision analysis framework. For Policy Econ. in Press. https://doi.org/10.1016/j.forpol.2017.07.002

European Parliament of the European Union and Council of the European Union (2009) Directive 2009/147/EC of the European Parliament and of the Council of 30 November 2009 on the conservation of wild birds. http://data.europa. eu/eli/dir/2009/147/2013-07-01. Accessed 7 Aug 2019

Eyvindson K, Repo A, Mönkkönen M (2018) Mitigating forest biodiversity and ecosystem service losses in the era of biobased economy. For Policy Econ 92:119-127. https://doi.org/10.1016/j.forpol.2018.04.009

Forest Resources (2018) Helsinki: Natural Resources Institute Finland. http://stat. luke.fi/en/tilasto/6221. Accessed 29 Aug 2018

Graf RF, Mathys L, Bollmann K (2009) Habitat assessment for forest dwelling species using LiDAR remote sensing: Capercaillie in the Alps. For Ecol Manag 257:160-167. https://doi.org/10.1016/j.foreco.2008.08.021

Haakana H, Hirvelä H, Hanski IK, Packalen T (2017) Comparing regional forest policy scenarios in terms of predicted suitable habitats for the Siberian flying squirrel (Pteromys volans). Scan J For Res 32(2):185-195. https://doi.org/10. 1080/02827581.2016.1221991

Hallikainen V, Hyppönen M, Pernu L, Puoskari J (2010) Family forest owners' opinions about forest management in northern Finland. Silva Fenn 44:363384. https://doi.org/10.14214/sf.158

Hauer G, Cumming S, Schmiegelow F, Adamowicz W, Weber M, Jagodzinski R (2010) Tradeoffs between forestry resource and conservation values under alternate policy regimes: a spatial analysis of the western Canadian boreal plains. Ecol Model 221:2590-2603. https://doi.org/10.1016/j.ecolmodel.2010.07.013

Heinonen T, Pukkala T, Mehtätalo L, Asikainen A, Kangas J, Peltola H (2017) Scenario analyses for the effects of harvesting intensity on development of forest resources, timber supply, carbon balance and biodiversity of Finnish forestry. For Policy Econ 80:80-98. https://doi.org/10.1016/j.forpol.2017.03.011

Helle P, Helle T (1991) How do changes in forest structure explain recent changes in Finnish grouse populations. Suomen Riista 37:56-66 (in Finnish with English summary)

Helle P, Lindström J (1991) Censusing tetraonids by the Finnish wildlife triangle method: principles and some applications. Ornis Fenn 68:148-157

Hirzel AH, Hausser J, Chessel D, Perrin N (2002) Ecological-niche factor analyses: how to compute habitat-suitability maps without absence data? Ecology 83:20272036. https://doi.org/10.1890/0012-9658(2002)083[2027:ENFAHT]2.0.CO;2
Huhta E, Helle P, Nivala V, Nikula A (2017) The effect of human-modified landscape structure on forest grouse broods in two landscape types. Ecosphere 8(9):e01950. https://doi.org/10.1002/ecs2.1950

Hunting Act 615/1993 (1993) Ministry of Agriculture and Forestry. https://www. finlex.fi/en/laki/kaannokset/1993/en19930615. Accessed 7 Aug 2019

Hunting Decree 666/1993 (1993) Ministry of Agriculture and Forestry. https:// www.finlex.fi/en/laki/kaannokset/1993/en19930666. Accessed 7 Aug 2019

Hurme E, Kurttila M, Mönkkönen M, Heinonen T, Pukkala T (2007) Maintenance of flying squirrel habitat and timber harvest: a site-specific spatial model in forest planning calculations. Landsc Ecol 22:243-256. https://doi.org/10.1007/ s10980-006-9019-9

Hynynen J, Ojansuu R, Hökkä H, Siipilehto J, Salminen H, Haapala P (2002) Models for predicting stand development in MELA system. The Finnish Forest research institute, research papers 835

Hyvän metsänhoidon suositukset [Forest management practice recommendations] (2006) Metsätalouden kehittämiskeskus Tapio. Metsäkustannus Oy, Helsinki (in Finnish)

Kangas A, Kurttila M, Hujala T, Eyvindson K, Kangas J (2015) Decision support for forest management, 2nd edn. Managing Forest Ecosystems 30, Springer. https://doi.org/10.1007/978-3-319-23522-6

Kangas J, Pukkala T (1996) Operationalization of biological diversity as a decision objective in tactical forest planning. Can J For Res 26:103-111

Kardell L (1980) Occurrence and production of bilberry, lingonberry and raspberry in Swedish forests. For Ecol Manag 2:285-298. https://doi.org/10. 1016/0378-1127(79)90055-0

Kastdalen L, Wegge P (1985) Animal food in capercaillie and black grouse chicks in south-East Norway. Int Grouse Symp 3:498-508

Katila M, Tomppo E (2001) Selecting estimation parameters for the Finnish multisource National Forest Inventory. Remote Sens Environ 76(1):16-32. https://doi.org/10.1016/S0034-4257(00)00188-7

Kauhala K, Helle P (2002) The impact of predator abundance on grouse populations in Finland: a study based on wildlife monitoring counts. Ornis Fenn 79:14-25

Keating KA, Cherry S (2004) Use and interpretation of logistic regression in habitat-selection studies. J Wildl Manag 68:774-789 http://www.jstor.org/ stable/3803634. Accessed 7 Aug 2019

Klaus S (1991) Effects of forestry on grouse populations: case studies from the Thuringian and bohemian forests, Central Europe. Ornis Scand 22:218-223. https://doi.org/10.2307/3676593

Kline JD, Harmon ME, Spies TA, Morzillo AT, Pabst RJ, McComb BC, Schnekenburger F, Olsen KA, Csuti B, Vogeler JC (2016) Evaluating carbon storage, timber harvest, and habitat possibilities for a Western cascades (USA) forest landscape. Ecol Appl 26:1-16. https://doi.org/10.1002/eap.1358

Korhonen KT, Ihalainen A, Ahola A, Heikkinen J, Henttonen HM, Hotanen J-P, Nevalainen S, Pitkänen J, Strandström M, Viiri H (2017) Suomen metsät 20092013 ja niiden kehitys 1921-2013. Luonnonvara- ja biotalouden tutkimus 59/ 2017. Luonnonvarakeskus, Helsinki, p 86 http://urn.fi/URN:ISBN:978952-326-467-0. Accessed 7 Aug 2019

Kurki S, Helle P, Lindén H, Nikula A (1997) Breeding success of black grouse and capercaillie in relation to mammalian predator densities on two spatial scales. Oikos 79:301-310. https://doi.org/10.2307/3546014

Kurki S, Lindén H (1995) Forest fragmentation due to agriculture affects the reproductive success of ground-nesting black grouse Tetrao tetrix. Ecography 18:109-113 http://www.jstor.org/stable/3682758. Accessed 7 Aug 2019

Kurki S, Nikula A, Helle P, Lindén H (1998) Abundance of red fox and pine marten in relation to the composition of boreal forest landscapes. J Anim Ecol 67: 874-886. https://doi.org/10.1046/j.1365-2656.1998.6760874.x

Kurki S, Nikula A, Helle P, Lindén H (2000) Landscape fragmentation and forest composition effects on grouse breeding success in boreal forests. Ecology 81: 1985-1997. https://doi.org/10.1890/0012-9658(2000)081[1985:LFAFCE]2.0.CO;2

Kvasnes MAJ, Storaas T (2007) Effects of harvesting regime on food availability and cover from predators in capercaillie (Tetrao urogallus) brood habitats. Scan J For Res 22:241-247. https://doi.org/10.1080/02827580701345884

Lappi J (1992) JLP: a linear programming package for management planning. The Finnish Forest Research Institute, Research Papers 414, Helsinki, p 134. http://mela2.metla.fi/mela/j/oppaat-en.htm. Accessed 20 Mar 2020

Lindén H (1981) Estimation of juvenile mortality in the capercaillie, Tetrao urogallus, and the black grouse, Tetrao tetrix, from indirect evidence. Finn Game Res 39:35-51

Lindén H (1988) Latitudinal gradients in predatorprey interactions, cyclicity and synchronism in voles and small game populations in Finland. Oikos 52:341349. https://doi.org/10.2307/3565208 
Lindén H, Helle E, Helle P, Wikman M (1996) Wildlife triangle scheme in Finland: methods and aims for monitoring wildlife populations. Finn Game Res 49:4-11

Lindén M, Lilja-Rothsten S, Saaristo L, Keto-Tokoi P (2014) Metsänhoidon suositukset riistametsänhoitoon, työopas. Metsätalouden kehittämiskeskus Tapio (in Finnish)

Lindström J, Ranta E, Kaitala V, Lindén H (1995) The clockwork of Finnish tetraonid population dynamics. Oikos 74:185-194. https://doi.org/10.2307/ 3545647

Ludwig GX, Alatalo RV, Helle P, Lindén H, Lindström J, Siitari H (2006) Short- and long-term population dynamical consequences of asymmetric climate change in black grouse. Proc Biol Sci 273(1597):2009-2016. https://doi.org/10. 1098/rspb.2006.3538

Mäkelä H, Hirvelä H, Nuutinen T, Kärkkäinen L (2011) Estimating forest data for analyses of forest production and utilization possibilities at village-level by means of multi-source National Forest Inventory. For Ecol Manag 262:13451359. https://doi.org/10.1016/j.foreco.2011.06.027

Marcström V, Kenward RE, Engren E (1988) The impact of predation on boreal tetraonids during vole cycles: an experimental study. J Anim Ecol 57:859-872

Mas-Colell A, Whinston MD, Green JR (1995) Microeconomic theory. Oxford University Press, Inc., New York, p 981

McCormick K, Kautto N (2013) The bioeconomy in Europe: an overview. Sustainability 5:2589-2608. https://doi.org/10.3390/su5062589

MELA Summary Reports (2018) Natural Resources Institute Finland. https://www. luke.fi/mela-cutting-possibilities/. Accessed 29 Aug 2018

Melin M, Mehtätalo L, Miettinen J, Tossavainen S, Packalen P (2016) Forest structure as a determinant of grouse brood occurrence - an analysis linking LiDAR data with presence/absence field data. For Ecol Manag 380:202-211. https://doi.org/10.1016/j.foreco.2016.09.007

Metsäkeskus (2016a) Pohjois-Karjalan metsäohjelma 2016-2020. https://www. metsakeskus.fi/sites/default/files/smk-alueellinen-metsaohjelma-pohjoiskarjala.pdf (in Finnish). Accessed 29 Aug 2018

Metsäkeskus (2016b) Lounais-Suomen metsäohjelma 2016-2020. https://www. metsakeskus.fi/sites/default/files/smk-alueellinen-metsaohjelma-lounais-suomi. pdf (in Finnish). Accessed 29 Aug 2018

Miettinen J, Helle P, Nikula A, Niemelä P (2008) Large-scale landscape composition and Capercaillie (Tetrao urogallus) density in Finland. Ann Zool Fenn 45:161-173

Miettinen J, Helle P, Nikula A, Niemelä P (2010) Capercaillie (Tetrao urogallus) habitat characteristics in North-Boreal Finland. Silva Fenn 44(2):235-254. https://doi.org/10.14214/sf.151

Moilanen A, Hanski I (1995) Habitat destruction and coexistence of competitors in a spatially realistic metapopulation model. J Anim Ecol 64:141-144. https:// doi.org/10.2307/5836

Mönkkönen M, Juutinen A, Mazziotta A, Miettinen K, Podkopaev D, Reunanen P, Salminen H, Tikkanen O-P (2014) Spatially dynamic forest management to sustain biodiversity and economic returns. J Environ Manag 134:80-89. https://doi.org/10.1016/j.jenvman.2013.12.021

Moss R, Oswald J (1985) Population dynamics of capercaillie in a northeast Scottish glen. Ornis Scand 16:229-238

Nalle DJ, Montgomery CA, Arthur JL, Polasky S, Schumaker NH (2004) Modeling joint production of wildlife and timber. J Environm Econ Manag 48:9971017. https://doi.org/10.1016/j.jeem.2004.01.001

National Forest Strategy 2025 - Government Resolution of 12 February 2015 (2015) Ministry of Agriculture and Forestry. Edita Prima, Helsinki 2015. ISBN 978-952-453-912-8. https://mmm.fi/en/nfs. Accessed 29 Aug 2018

Natural Resources Institute Finland (Luke) (2019) Luonnonvarakeskus (Luke) (in Finnish). http://www.Riistakolmiot.fi. Accessed 5 Aug 2019

Nilsson M (1997) Estimation of forest variables using satellite image data and airborne Lidar. Acta Universitatis Agriculturae Suecia. Silvestria 17. Swedish University of Agricultural Sciences, Department of forest resource management and geomatics, Umeå

Nilsson P, Cory N (2017) Forest statistics 2017 official statistics of Sweden. Swedish University of Agricultural Sciences, Umeå

Nordström E-M, Holmström H, Öhman K (2013) Evaluating continuous cover forestry based on the forest owner's objectives by combining scenario analysis and multiple criteria decision analysis. Silva Fenn. https://doi.org/10. $14214 /$ sf.1046

Nuutinen T, Hirvelä H (2006) Hakkuumahdollisuudet Suomessa valtakunnan metsien 10. Inventoinnin perusteella [Forest production possibilities according to the 10th National Forest Inventory]. Metsätieteen aikakauskirja 1B/2006:223-237 (in Finnish)
Nuutinen T, Hirvelä H, Hynynen J, Härkönen K, Hökkä H, Korhonen KT, Salminen $\mathrm{O}$ (2000) The role of peatlands in Finnish wood production- an analysis based on large-scale forest scenario modelling. Silva Fenn 34(2):131-153

Official Statistics of Finland (OSF) (2018) Total roundwood removals and drain. Natural Resources Institute Finland, Helsinki http://stat.luke.fi/en/roundwoodremovals-and-drain. Accessed 29 Aug 2018

Pearce J, Boyce MS (2006) Modelling distribution and abundance with presence-only data. J Appl Ecol 43:405-412. https://doi.org/10.1111/j.1365-2664.2005.01112.x

Pearce J, Ferrier S (2000) Evaluating the predictive performance of habitat models developed using logistic regression. Ecol Model 133:225-245. https://doi.org/ 10.1016/S0304-3800(00)00322-7

Pukkala T (2008) Integrating multiple services in the numerical analysis of landscape design. In: von Gadow K, Pukkala T (eds) Designing Green landscapes, managing Forest ecosystems, vol 15. Springer, Dordrecht, pp 137-167. https://doi.org/10.1007/978-1-4020-6759-4_6

Pukkala T (2016) Which type of forest management provides most ecosystem services? Forest Ecosyst 3:9. https://doi.org/10.1186/s40663-016-0068-5

Rajala P (1974) The structure of and reproduction of Finnish populations of capercaillie, Tetrao urogallus, and black grouse, Lyrurus tetrix, on the basis of late summer census data from 1963 to 1966. Finn Game Res 35:1-151

Redsven V, Hirvelä H, Härkönen K, Salminen O, Siitonen M (2007) MELA2007 reference manual. The Finnish Forest Research Institute, p 642 http://mela2 metla.fi/mela/julkaisut/oppaat/mela2007.pdf. Accessed Mar 32018

Reese H, Nilsson M, Granqvist Pahlén T, Hagner O, Joyce S, Tingelöf U, Egberth M, Olsson H (2003) Countrywide estimates of forest variables using satellite data and field data from the national forest inventory. AMBIO 32:542-548. https://doi.org/10.1579/0044-7447-32.8.542

Rolstad J (1989) Habitat and range use of capercaillie Tetrao urogallus L. in southcentral Scandinavian boreal forests, with special reference to the influence of modern forestry. Dissertation, Department of Nature Conservation, Agricultural University of Norway, As

Rolstad J, Wegge P, Larsen BB (1988) Spacing and habitat use of capercaillie during summer. Can J Zool 66:670-679. https://doi.org/10.1139/z88-099

Salminen O, Hirvelä H, Härkönen K (2013) Valtakunnan metsien 10. inventointiin perustuvat ainespuun alueelliset hakkuumahdollisuusarviot. Metsätieteen aikakauskirja 3:199-268 (in Finnish). https://doi.org/10.14214/ma.6024

Seidl R, Rammer W, Jäger D, Currie WS, Lexer MJ (2007) Assessing trade-offs between carbon sequestration and timber production within a framework of multi-purpose forestry in Austria. For Ecol Manag 248:64-79. https://doi.org/ 10.1016/j.foreco.2007.02.035

Sievänen R, Salminen O, Lehtonen A, Ojanen P, Liski J, Ruosteenoja K, Tuomi M (2014) Carbon stock changes of forest land in Finland under different levels of wood use and climate change. Ann For Sci 71:255-265. https://doi.org/10. 1007/s13595-013-0295-7

Siitonen M, Härkönen K, Hirvelä H, Jämsä J, Kilpeläinen H, Salminen O, Teuri M (1996) MELA handbook - 1996 edition. The Finnish Forest Research Institute, Research Papers 622, Helsinki, p 452

Sirkiä S, Lindén A, Helle P, Nikula A, Knape J, Lindén H (2010) Are the declining trends in forest grouse populations due to changes in the forest age structure? A case study of Capercaillie in Finland. Biol Conserv 143:15401548. https://doi.org/10.1016/j.biocon.2010.03.038

Storaas T, Kastdalen L, Wegge P (1999) Detection of forest grouse by mammalian predators: a possible explanation for high brood losses in fragmented landscapes. Wildl Biol 5:187-192. https://doi.org/10.2981/wlb.1999.016

Storch I (1993) Habitat selection by capercaillie in summer and autumn: is bilberry important? Oecologia 95:257-265. https://doi.org/10.1007/ BF00323498

Suomen metsäkanalintukantojen hoitosuunnitelma (2014) Maa- ja metsätalousministeriö. 10/2014 (in Finnish). http://urn.fi/URN:ISBN:978952-453-873-2. Accessed 7 Aug 2019

The Finnish Bioeconomy Strategy (2014) Sustainable growth from bioeconomy. Edita Prima Ltd, May 2014. https://mmm.fi/en/bioeconomy/strategies-andprogrammes. Accessed 7 Aug 2019

Tikkanen O-P, Heinonen T, Kouki J, Matero J (2007) Habitat suitability models of saproxylic red-listed boreal forest species in long-term managements: cost effective measures for multi-species conservation. Biol Conserv 140:359-372. https://doi.org/10.1016/j.biocon.2007.08.020

Tomppo E, Haakana M, Katila M, Mäkisara K, Peräsaari J (2009) The multi-source National Forest Inventory of Finland - methods and results 2005, vol 111. Working Papers of the Finnish Forest Research Institute http://www.metla.fi/ julkaisut/workingpapers/2009/mwp111.pdf. Accessed 7 Aug 2019 
Tomppo E, Haakana M, Katila M, Peräsaari J (2008) Multi-source National Forest Inventory. Methods and applications. Managing Forest ecosystems, vol 18. Springer, Netherlands, p 374

Tonteri T, Salemaa M, Rautio P, Hallikainen V, Korpela L, Merilä P (2016) Forest management regulates temporal change in the cover of boreal plant species. For Ecol Manag 381:115-124. https://doi.org/10.1016/j.foreco.2016.09.015

Trzcinski MK, Fahrig L, Merriam G (1999) Independent effects of forest cover and fragmentation on the distribution of forest breeding birds. Ecol Appl 9:586-593

Turtiainen M, Miina J, Salo K, Hotanen J-P (2016) Modelling the coverage and annual variation in bilberry yield in Finland. Silva Fenn 50. https://doi.org/10 14214/sf.1573

Uhde B, Hahn WA, Griess VC, Knoke T (2015) Hybrid MCDA methods to integrate multiple ecosystem services in forest management planning: a critical review. Environ Manag 56:373-388. https:/doi.org/10.1007/s00267-015-0503-3

Uotila A, Kouki J (2005) Understory vegetation in spruce-dominated forests in eastern Finland and Russian Karelia: successional patterns after anthropogenic and natural disturbances. For Ecol Manag 215:113-137. https://doi.org/10.1016/.jforeco.2005.05.008

Valkama J, Vepsäläinen V, Lehikoinen A (2011) Suomen III Lintuatlas. Luonnontieteellinen keskusmuseo ja ympäristöministeriö. http://atlas3. lintuatlas.fi ISBN 978-952-10-6918-5. Accessed 20 Aug 2018

Wegge P, Rolstad J (2011) Clearcutting forestry and Eurasian boreal forest grouse: long-term monitoring of sympatric capercaillie Tetrao urogallus and black grouse $T$. tetrix reveals unexpected effects on their population performances. For Ecol Manag 261(9):1520-1529. https://doi.org/10.1016/j.foreco.2011.01.041 Wegge P, Rolstad J, Gjerde I, Kastdalen I, Storaas T (1990) Does forest fragmentation increase the mortality pattern of capercaillie? Transnational 19th IUGB congress. The Nordic Board for Wildlife Research, Trondheim, pp $448-453$

Wilcox BA, Murphy DD (1985) Conservation strategy: the effects of fragmentation on extinction. Am Nat 125:879-887

Zellweger F, Braunisch V, Baltensweiler A, Bollmann K (2013) Remotely sensed forest structural complexity predicts multi species occurrence at the landscape scale. For Ecol Manag 307:303-312. https://doi.org/10.1016/j. foreco.2013.07.023

\section{Submit your manuscript to a SpringerOpen ${ }^{\circ}$ journal and benefit from:}

- Convenient online submission

- Rigorous peer review

- Open access: articles freely available online

- High visibility within the field

- Retaining the copyright to your article

Submit your next manuscript at $\boldsymbol{\nabla}$ springeropen.com 